\title{
Cardiovascular risk factor investigation: a pediatric issue
}

This article was published in the following Dove Press journal:

International Journal of General Medicine

4 March 2013

Number of times this article has been viewed

\section{Anabel N Rodrigues' \\ Glaucia R Abreu ${ }^{2}$ \\ Rogério S Resende' Washington LS Goncalves' Sonia Alves Gouvea ${ }^{2}$ \\ 'School of Medicine, University Center of Espírito Santo, Colatina, Brazil; ${ }^{2}$ Postgraduate Program in Physiological Sciences, Center for Health Sciences, Federal University of Espirito Santo, Vitória, Brazil}

Correspondence: Anabel Nunes Rodrigues Avenida Fioravante Rossi, 2930 Bairro Martinelli, Colatina, ES 29705-900, Brazil

Tel +5I 2737233000

Fax +5I 2737233000

Email anabel@anabelnunes.org
Objectives: To correlate cardiovascular risk factors (e.g., hypertension, obesity, hypercholesterolemia, hypertriglyceridemia, hyperglycemia, sedentariness) in childhood and adolescence with the occurrence of cardiovascular disease.

Sources: A systematic review of books and selected articles from PubMed, SciELO and Cochrane from 1992 to 2012.

Summary of findings: Risk factors for atherosclerosis are present in childhood, although cardiovascular disease arises during adulthood. This article presents the main studies that describe the importance of investigating the risk factors for cardiovascular diseases in childhood and their associations. Significant rates of hypertension, obesity, dyslipidemia, and sedentariness occur in children and adolescents. Blood pressure needs to be measured in childhood. An increase in arterial blood pressure in young people predicts hypertension in adulthood. The death rate from cardiovascular disease is lowest in children with lower cholesterol levels and in individuals who exercise regularly. In addition, there is a high prevalence of sedentariness in children and adolescents.

Conclusions: Studies involving the analysis of cardiovascular risk factors should always report the prevalence of these factors and their correlations during childhood because these factors are indispensable for identifying an at-risk population. The identification of risk factors in asymptomatic children could contribute to a decrease in cardiovascular disease, preventing such diseases as hypertension, obesity, and dyslipidemia from becoming the epidemics of this century.

Keywords: Cardiovascular risk, Children, Hypertension, Obesity, Dyslipidemia, Sedentariness, Metabolic syndrome.

\section{Introduction}

Childhood is considered the structuring period of life, during which such patterns as diet and lifestyle are formed and fixed. Although atherosclerotic disease (AD) becomes symptomatic later in life, the early identification of predisposing factors and lifestyle modifications can significantly reduce the incidence of AD. ${ }^{1}$ Findings indicating that atherosclerosis begins in childhood are not new and were first presented by Saltykow in 1915 in studies involving autopsies of young patients. Atherosclerosis has been appreciated as a pediatric problem since $1965 .^{2}$

Coronary atherosclerosis, a disease as old as the human species, is undoubtedly the best-documented pathology. ${ }^{3,4}$ This process begins in early childhood, and is highly reversible at that stage. ${ }^{5}$ Children usually do not develop atherosclerosis; however, they develop fatty streaks that are reversible. ${ }^{6}$ Reports in the medical literature show that the degree of atherosclerosis in children and young adults can be correlated with the same 
risk factors identified in adults, and minimizing or reducing these known risk factors is prudent. ${ }^{7,8}$ Therefore, investigating risk factors for that stage of life is fundamentally important, because these risk factors can have profound implications for disease manifestations in adulthood. ${ }^{9-12}$

\section{Sources}

In this systematic review, we analyze the main cardiovascular risk factors present in childhood and their prevalence. Electronic searches were conducted for selected articles from PubMed, SciELO, and Cochrane from 1992 to 2012 using the following terms: physical activity, cardiovascular risk factors, obesity in childhood, children and adolescents, hypertension in childhood, and atherosclerotic disease. Searches for books, dissertations, and theses were performed using the Google Scholar search tool. There was no language restriction. Four researchers independently evaluated the titles that were identified in the initial search. Two authors independently reviewed the articles selected from the initial search for methodological quality, number of subjects studied, and results demonstrated. Studies with dubious methodologies or with very low numbers of assessed individuals and studies that repeated information that was available in other studies were excluded. In the latter case, preference was given to the most recent study and to the study with the greatest number of individuals assessed, respectively. Disagreements were resolved by consensus. The identification of risk factors in children in combination with cooperative action by public agencies and medical professionals, especially pediatricians

Table I Distribution of references according to continent and country

\begin{tabular}{lll}
\hline Continents & Country & $\begin{array}{l}\text { References } \\
\mathbf{n}=\mathbf{~ I ~ I 2 ~}\end{array}$ \\
\hline Americas & United States & 42 \\
(8I references) & Canada & 3 \\
& Brazil & 36 \\
Europe & United Kingdom & 12 \\
(26 references) & Finland & 4 \\
& Belgium & 2 \\
& Denmark & 2 \\
& France & 2 \\
& Spain & 2 \\
Asia & Hungary & $\mathrm{I}$ \\
(4 references) & Netherlands & $\mathrm{I}$ \\
& Saudi Arabia & $\mathrm{I}$ \\
Oceania & Iran & 2 \\
(I reference) & Japan & $\mathrm{I}$ \\
Total & Australia & $\mathrm{I}$ \\
\hline
\end{tabular}

and cardiologists, can produce positive effects for one of the world's major public health problems. Table 1 shows the distribution of the references according to continent and country.

\section{Cardiovascular risk factors Overview of associated factors}

The finding that AD begins at an early stage of life reveals childhood and adolescence as critical periods for the detection of risk factors for cardiovascular disease and the prevention of future complications. Monitoring these factors would help identify early signs that when modified can mitigate or even reverse the progression of those dysfunctions. A range of risk factors, including genetic factors, hypertension, dyslipidemia, obesity, metabolic syndrome (MS), an atherogenic diet, and physical inactivity, is associated with cardiovascular disease, and the prevalence of these factors is increasing among children and adolescents. ${ }^{13-17}$

Lifestyle and eating habits are fundamentally important for protection against the manifestation and progression of $\mathrm{AD}$ risk factors. $\mathrm{AD}$ is considered the main causal factor for cardiovascular disease, ${ }^{18,19}$ and therefore should be a key target of heart disease-prevention programs. ${ }^{20}$ The emphasis is on hypercholesterolemia, hypertriglyceridemia, overweight, hyperglycemia, hypertension, and physical inactivity. ${ }^{21}$ Correlations between the plasma levels of cholesterol and a decrease or delay in $\mathrm{AD}$ progression by means of diet and lifestyle changes have been documented, ${ }^{22}$ with the hypothesis that for each $1 \%$ reduction in total cholesterol, a decrease of $2 \%$ in the occurrence of coronary artery disease was observed. Studies have also reported that the degree of atherosclerosis in children and young adults can be correlated with the same risk factors that have been identified in adults. Therefore, an increase in the incidence of cardiovascular disease is likely to occur when current teens enter adulthood. Thus, as in other age-groups, it is prudent to minimize or reduce risk factors in youth. ${ }^{7}$

\section{Atherosclerosis}

Although AD becomes symptomatic later in life, the early identification and modification of risk factors can reduce its later incidence. ${ }^{1}$ These diseases are currently the most common causes of death. Studies suggest that the AD process is as old as the human species. ${ }^{3,23}$ AD begins in childhood; therefore, its prevention should begin early, because at this stage it is considered reversible, with high levels of blood lipoproteins playing a fundamental role in its manifestation. ${ }^{24}$ In children, fatty streaks in the aorta, although reversible, 
Table 2 Recommended lipid levels in adolescents aged up to 19 years

\begin{tabular}{llll}
\hline Lipids & Desired & $\begin{array}{l}\text { Borderline } \\
(\mathbf{m g} / \mathbf{d L})\end{array}$ & $\begin{array}{l}\text { Elevated } \\
\mathbf{( m g / d L})\end{array}$ \\
\hline $\mathrm{TC}(\mathrm{mg} / \mathrm{dL})$ & $<150$ & $150-169$ & $\geq 170$ \\
$\mathrm{LDL}-\mathrm{c}(\mathrm{mg} / \mathrm{dL})$ & $<100$ & $100-129$ & $\geq 130$ \\
$\mathrm{HDL}-\mathrm{c}(\mathrm{mg} / \mathrm{dL})$ & $\geq 45$ & & $\geq 130$ \\
$\mathrm{TGs}(\mathrm{mg} / \mathrm{dL})$ & $<100$ & $100-129$ & $\geq 10$ \\
\hline
\end{tabular}

Abbreviations: TC, total cholesterol; LDL-c, low-density lipoprotein cholesterol; HDL-c, high-density lipoprotein cholesterol; TGs, triglycerides.

arise at around 3 years of age and already compromise $15 \%$ of this artery by 15 years of age. Several studies cited by Françoso and Coates ${ }^{23}$ present evidence of fatty streaks and fibrous plaques in the coronary arteries of adolescents between 10 and 14 years of age and thickening of the inner layer (intima) of the coronary arteries in children less than 5 years of age. Researchers have demonstrated that a fatty diet and other traditional vascular risk factors begin to influence blood lipid levels during the early years of life. ${ }^{6,23}$

Due to the variety of criteria used to define optimal lipid levels in adolescents, it is difficult to compare results from across the world. However, studies have shown, for example, the presence of atheromatosis in aortic intima with cholesterol levels between 140 and $170 \mathrm{mg} / \mathrm{dL}$. Thus, the epidemiological goals for plasma cholesterol in children would be an average of $150 \mathrm{mg} / \mathrm{dL}^{8}$

In a review of studies conducted in 26 countries (from 1975 to 1996) involving 60,494 children and adolescents aged $2-19$ years, Brotons et $\mathrm{al}^{25}$ found an average of $165 \mathrm{mg} / \mathrm{dL}$ for cholesterol, $60 \mathrm{mg} / \mathrm{dL}$ for HDL-cholesterol, and $67 \mathrm{mg} / \mathrm{dL}$ for triglycerides. Table 2 demonstrates the lipid levels recommended in adolescents up to 19 years of age. ${ }^{26}$

Studies conducted in Brazil revealed higher levels of cholesterol in adolescents attending private schools compared to those attending public school. ${ }^{11,27}$ This trend was confirmed by other studies ${ }^{15,28,29}$ that showed that adolescents with lower family income and those that attend public schools have lower cholesterol levels than adolescents from higher-income families and private schools. These data support Guimarães's and Guimarães's ${ }^{29}$ proposition that families with higher socioeconomic levels do not necessarily have a better and healthier lifestyle. The lower household income in developing countries may prevent these children from consuming high levels of calories in diets heavy in saturated fats and cholesterol. In addition, students of public schools tend to expend more energy in their daily lives because they need to walk to school or use public transportation.

Despite methodological limitations for calculating lowdensity lipoprotein cholesterol as part of the lipid profile, its measurement is widely regarded as the gold standard for both risk assessment and intervention programs for cardiovascular diseases. ${ }^{8}$ Because triglycerides are deposited on the vessel wall and initiate the process of low-density lipoprotein accumulation, they are strongly associated with the risk of developing AD. ${ }^{30,31}$

Whether breastfeeding during the first year of life confers protection against future increases in the levels of plasma

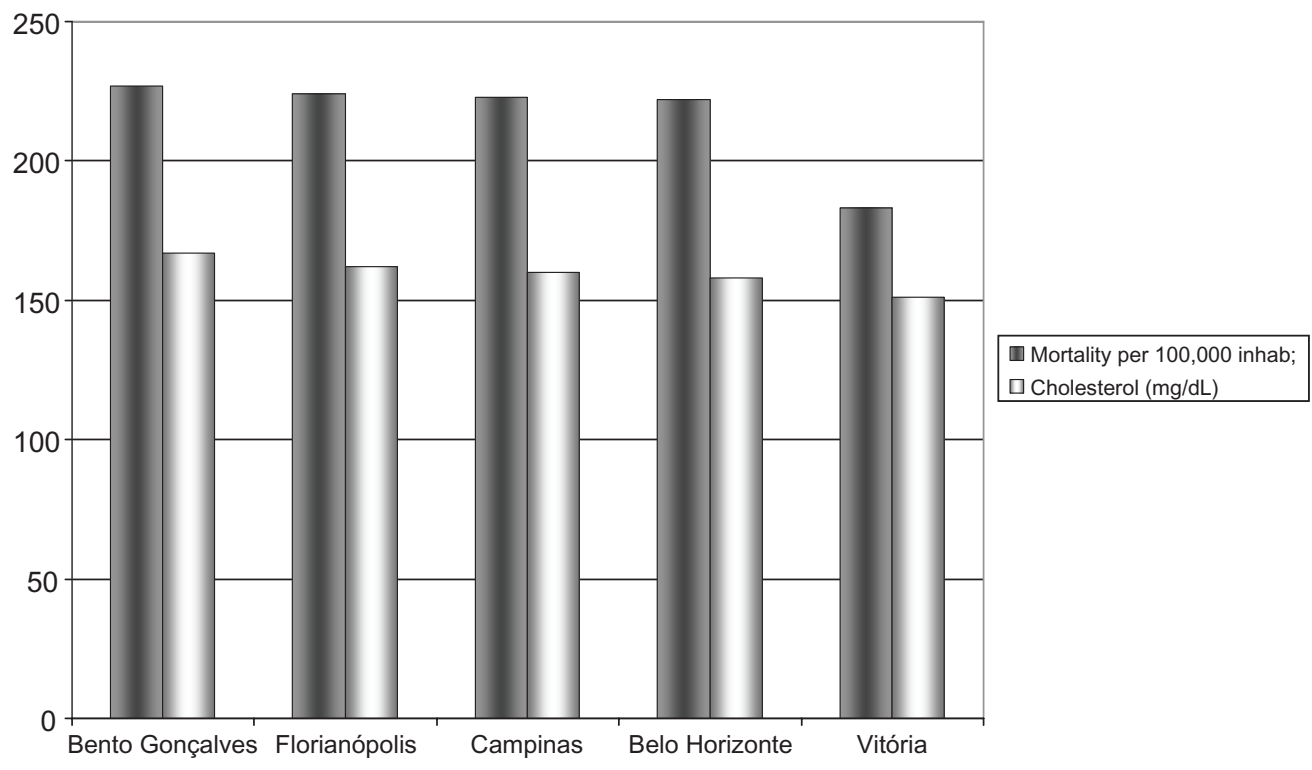

Figure I Relationship between cholesterol levels in adolescents and mortality from circulatory diseases in Brazil's cities. Note: Mortality per 100,000 inhabitants. 
lipids and mortality by $\mathrm{AD}$ is controversial. ${ }^{32}$ The major health advantage of breastfeeding that has been clearly demonstrated remains in the protection of the infant from certain infections in early life. If there are other long-term health advantages, they have yet to be fully elucidated and confirmed. Dyslipidemia that begins during childhood tends to be maintained through development, and studies describe a direct relationship between total cholesterol levels in children and heart disease in adults. ${ }^{33}$ Studies conducted in Brazil ${ }^{15,27,34}$ have shown that cholesterol levels in adolescence correlated with $87 \%$ of deaths due to heart disease in adulthood (Figure 1) and showed that high levels of cholesterol are accompanied by a high mortality rate.

An association between inflammatory processes and the development of atherosclerosis has recently been described, providing important correlations for understanding the mechanisms of atherogenesis and risk factors. Several studies have examined different markers of inflammation in the bloodstream, such as cytokines and adhesion molecules, as potential predictors for the risk of heart disease. Some clinical studies have suggested that serum levels of tumor necrosis factor- $\alpha$, interleukin-6, and C-reactive protein are elevated in patients with congestive heart failure, regardless of the etiology of the condition. Furthermore, elevated blood levels of these inflammatory markers correlate with worsening functional class, increased hospitalization rates, and poorer survival. ${ }^{35-38}$ In addition, structural and functional changes have been observed in the arteries of children with a familial predisposition for AD, and these changes are associated with groups of inflammatory factors and oxidation markers. During the development of atheromatous plaques, inflammation plays an essential role in the destabilization of arterial plaques, and in turn is associated with acute thromboembolic diseases. Because lifestyle-modification trials have been successful in decreasing endothelial dysfunction and levels of inflammation markers among children and adolescents, controlling the inflammatory process is suggested in addition to expanding pharmacological therapies, which are considered a secondary means of preventing AD. ${ }^{39}$

\section{Obesity}

Obesity (more specifically, excessive adiposity), which is defined as an excessive accumulation of body fat, is a heterogeneous disorder with a common final pathway in which energy intake chronically exceeds energy expenditure. Obesity features a combination of genetic and environmental factors. ${ }^{40}$ The energy imbalance often begins in childhood, and when this imbalance occurs the likelihood of obesity in adulthood increases. Among young people, the prevalence of obesity has greatly increased in recent years and represents the most common chronic disorder. ${ }^{41}$ Excessive adiposity in childhood represents a greater risk to adult health than obesity starting in adulthood. Adults who were overweight as adolescents have an increased risk of diseases compared with adults who were of normal weight as adolescents. ${ }^{42,43}$ Obesity is the result of a complex interaction of factors, including metabolic, physiological, environmental, genetic, behavioral, and social influences. The Bogalusa Heart Study in Louisiana (USA), which was conducted among children and adolescents, suggested significant correlations between obesity and both lipoprotein levels (low-density lipoprotein in particular) and insulinemia, which were correlated with the risk of cardiovascular diseases. ${ }^{44}$

Although it is unclear if childhood obesity is an independent risk factor for cardiovascular disease, studies show a clear association between severe obesity and increased mortality. The importance of childhood obesity as a risk factor for cardiovascular disease is increasingly evident. ${ }^{17,45}$ Obesity deserves particular attention because it is usually accompanied by two notorious and significant risk factors: diabetes and arterial hypertension. ${ }^{46,47}$ Therefore, controlling obesity during childhood is important because the obesity acquired during this period of life tends to persist into adulthood. ${ }^{11}$

Studies have reported a substantial increase in the number of overweight children and adolescents in recent decades, and this increase is associated with an increased risk of hypertension, lipid abnormalities, type II diabetes, early atherosclerotic lesions, adult obesity, and mortality in young adulthood. ${ }^{7,48-50}$ Preventing childhood obesity is the best opportunity to introduce changes in lifestyle and thus reduce cardiovascular morbidity and mortality. ${ }^{51-53}$ The diagnosis of overweight and obesity still presents difficulties, because the best criteria to determine these categories in this age-group remain unclear. One of the contested methods is the "cutoff point" for their identification. However, the body mass index, based on international standards, is useful, inexpensive, and replicable. ${ }^{54}$ Recently, the term "obesity" has been used to identify body mass index $\geq$ P95 in children and adolescents. ${ }^{50}$

Data on childhood and adolescent obesity around the world are still limited, and the lack of uniformity among definitions and studied age-ranges complicates comparisons of prevalence. Obesity in children and adolescents is increasing significantly, including in developing countries. ${ }^{55}$ A national study, Nutre Brasil Infância (Nourish Brazil Childhood), 
indicated that $23 \%$ of Brazilian children up to 5 years of age exhibit excess weight, ${ }^{56}$ while in developed countries, obesity mainly affects the lower-income social classes; in Brazil, for example, the most favored social classes are still the most affected, although there is a tendency toward change. The most recent studies conducted in Brazil reveal that the prevalence of overweight in children and adolescents ranges from $8.4 \%$ to $19 \%$, while that of obesity ranges from $3.1 \%$ to $18 \%,{ }^{54,57}$ furthermore, the prevalence of overweight and obesity is greater in higher-income households. ${ }^{58,59}$ The National Health and Nutrition Examination Survey estimated a prevalence of $30 \%$ for overweight and obesity $\geq$ P 85 and a prevalence of $15 \%$ for obesity $\geq$ P95 for the age-group between 6 and 19 years of age. ${ }^{60}$ In Brazil, studies stress the physical inactivity of children as one of the most important factors associated with obesity. ${ }^{49-54}$

\section{Metabolic syndrome}

MS is currently characterized as the combination of a number of risk factors for cardiovascular disease, including dyslipidemia, hypertension, carbohydrate-metabolism disorders, and obesity, especially abdominal obesity. ${ }^{61}$ In children, the global consensus regarding MS is still a matter of discussion. ${ }^{26} \mathrm{~A}$ direct association between obesity and insulin-resistance syndrome has been demonstrated in children, and was recently recognized as a major precursor of atherosclerotic cardiovascular disease and type II diabetes. $^{7,62}$

Although we do not have a global consensus to define and diagnose MS in adults and children, MS is associated with a 1.5-fold increase in overall mortality and a 2.5 -fold increase in cardiovascular mortality. ${ }^{63}$ Given its importance, various organizations, including the World Health Organization, ${ }^{64}$ the National Cholesterol Education Program Adult Treatment
Panel III, ${ }^{65}$ the European Group for the Study of Insulin Resistance, ${ }^{66}$ and the International Diabetes Federation, have proposed criteria to define and treat MS.

To determine the prevalence of MS in children and adolescents, either the adult criteria are modified for pediatric reference values, ${ }^{67}$ or specific cutoff points are used. ${ }^{68,69}$ Some studies suggest cutoff points corresponding to the 95th percentiles of each variable by sex and age and the height percentile when including blood pressure (BP). ${ }^{70,71}$ However, the lack of consensus means that the prevalence of this syndrome is markedly different in different studies. ${ }^{72}$ Table 3 demonstrates the definition considered most suitable for MS, according to the Department of Metabolic Syndrome of the Brazilian Society of Diabetes. ${ }^{26}$

Prospective studies have shown that obesity looms as the most important risk factor for MS and precedes the onset of insulin resistance by several years, ${ }^{62,73}$ insulin resistance is the leading cause of the hemodynamic and metabolic disorders of MS. ${ }^{74} \mathrm{MS}$ is caused by a combination of genetic and environmental factors in which obesity plays a primary role and leads to excessive production of insulin, which is associated with an increase in BP and dyslipidemia. ${ }^{50}$ An estimated 1 million US adolescents already meet the criteria for $\mathrm{MS},{ }^{50}$ with a prevalence of $4 \%$ between 12 and 19 years of age. In addition, MS is present in 30\%-50\% of overweight children. ${ }^{67,75}$

\section{Hypertension}

Identified as one of the most common precursors of coronary artery disease, hypertension is usually asymptomatic, and prevention is the most efficient way to fight it and avoid the high social cost of its treatment and complications. Therefore, the need to measure hypertension levels and identify those individuals with high BP is mandatory. The worldwide

Table 3 Classification of metabolic syndrome in children and adolescents

\begin{tabular}{|c|c|c|c|}
\hline \multirow[t]{2}{*}{ Criteria/components } & \multicolumn{3}{|l|}{ Age } \\
\hline & From 6 to 10 years & From 10 to 16 years & $>16$ years \\
\hline Definition of adiposity & $\mathrm{WC} \geq \mathrm{P} 90$ & $\mathrm{WC} \geq \mathrm{P} 90$ & $\begin{array}{l}W C \geq 90 \mathrm{~cm} \text { (boys) or } \\
\geq 80 \mathrm{~cm} \text { (girls) }\end{array}$ \\
\hline Glucose metabolism & $\begin{array}{l}\text { No defined cutoff value for the } \\
\text { diagnosis of metabolic syndrome }\end{array}$ & Fasting glucose $\geq 100 \mathrm{mg} / \mathrm{dL}$ & Fasting glucose $\geq 100 \mathrm{mg} / \mathrm{dL}$ \\
\hline Dyslipidemia & $\begin{array}{l}\text { No defined cutoff value for the } \\
\text { diagnosis of metabolic syndrome }\end{array}$ & $\begin{array}{l}\mathrm{TGs} \geq 150 \mathrm{mg} / \mathrm{dL} \text { or } \\
\mathrm{HDL}-\mathrm{C} \leq 40 \mathrm{mg} / \mathrm{dL} \text { or } \\
\text { ingesting ALD }\end{array}$ & $\begin{array}{l}\text { TGs } \geq 150 \mathrm{mg} / \mathrm{dL} \text { or } \\
\mathrm{HDL}-\mathrm{C} \leq 40 \mathrm{mg} / \mathrm{dL} \text { (boys) or } \\
\leq 50 \mathrm{mg} / \mathrm{dL} \text { (girls) or } \\
\text { ingesting ALD }\end{array}$ \\
\hline Hypertension & $\begin{array}{l}\text { No defined cutoff value for the } \\
\text { diagnosis of metabolic syndrome }\end{array}$ & $\begin{array}{l}\mathrm{SBP} \geq 130 \text { or } \mathrm{DBP} \geq 85 \mathrm{mmHg} \text { or } \\
\text { ingesting } \mathrm{AHD}\end{array}$ & $\begin{array}{l}\mathrm{SBP} \geq 130 \text { or } \mathrm{DBP} \geq 85 \mathrm{mmHg} \text { or } \\
\text { ingesting } \mathrm{AHD}\end{array}$ \\
\hline
\end{tabular}

Abbreviations: WC, waist circumference; TGs, triglycerides; HDL-C, high-density lipoprotein cholesterol; ALD, antilipidemic drug; DBP, diastolic blood pressure; SBP, systolic blood pressure; AHD, antihypertensive drug. 
prevalence of hypertension in children is highly variable ( $2 \%-13 \%)$, depending on the methodology employed. In Brazil, for example, it is estimated that the prevalence of hypertension in children and adolescents is $4 \%,{ }^{76}$ and the need for BP measurement is considered imperative from 3 years of age. Arterial BP commonly rises with age, and its elevation in children is a prediction of hypertension in adulthood that may have started in childhood or adolescence.,77-80

BP should be interpreted as a result of the impact of environmental influences on the expression of several genes that in turn regulate other genes. It is influenced by angiotensinconverting enzyme gene expression and for endothelial NO synthase gene expression. ${ }^{81,82}$ Several known factors related to hypertension in adults, such as sex, age, family history, and the presence of increased body weight or obesity, are also observed in children and adolescents.$^{83}$ High BP contributes to the development of cardiovascular complications. Its association with multiple risk factors has a multiplier effect on the risk of cardiovascular events. ${ }^{84-86}$

Hypertension is diagnosed when the values of systolic BP and/or diastolic BP are greater than or equal to the 95 th percentile for sex, age, and height, plus $5 \mathrm{mmHg}$, on three separate occasions. A prehypertensive group should also be defined and identified with the purpose of adopting stringent preventive measures. BP values $\geq 90$ th percentile and $<95$ th percentile characterize prehypertension; values that are included in this range and exceed the limits of $120 / 80 \mathrm{mmHg}$ should also be considered as prehypertensive and follow the same recommendations proposed by the Seventh Report of the Joint National Committee on Prevention, Detection, Evaluation, and Treatment of High Blood Pressure (JNC 7) ${ }^{85}$ for adults. Table 4 summarizes the classification of BP for children and adolescents. ${ }^{87}$

Table 4 Classification of blood pressure for children and adolescents (modified from the fourth report on the diagnosis, evaluation and treatment of high blood pressure in children and adolescents) $^{87}$

\begin{tabular}{ll}
\hline Classification & Percentile* for SBP and DBP \\
\hline Normal & $\mathrm{BP}<\mathrm{P90}$ \\
Borderline & $\mathrm{BP}$ between $\mathrm{P90}$ and $\mathrm{P95}$ or if PA exceeds \\
& $120 / 80 \mathrm{mmHg}$, always $>\mathrm{P} 90$ and $<\mathrm{P95}$ \\
Hypertension stage I & $\mathrm{P} 95$ to $\mathrm{P} 99 \mathrm{plus} 5 \mathrm{mmHg}$ \\
Hypertension stage 2 & $\mathrm{BP}>\mathrm{P} 99$ plus $5 \mathrm{mmHg}$ \\
White-coat & $\mathrm{BP}>\mathrm{P95}$ in outpatient clinic or ambulatory \\
hypertension & and normal BP in environments nonrelated \\
& to clinical practice \\
\hline
\end{tabular}

Note: *For age, sex, and height percentile.

Abbreviations: BP, blood pressure; DBP, diastolic blood pressure; SBP, systolic blood pressure.
It is estimated that $30 \%$ of children and adolescents with overweight/obesity have hypertension. ${ }^{88}$ Thus, the presence of overweight/obesity appears to be one of the most important factors related to hypertension in children and adolescents worldwide ${ }^{85,89,90}$ Several studies have shown that the presence of overweight/obesity is positively correlated with the occurrence of prehypertension in children and adolescents, and this combination increases the risk of developing adult hypertension. ${ }^{91-94}$ Certain conditions are strongly associated with hypertension in teens, including smoking and the use of contraceptives, alcohol, cocaine, amphetamines, anabolic steroids, phenylpropanolamine, and pseudoephedrine (nasal decongestants).

Therefore, changes in lifestyle, such as weight control, reduction in sodium intake, and exercise, are fundamental for the prevention of hypertension. Although threshold pressure levels are not yet well defined, BP most likely affects target organs in children, as in adults. Dietary intervention, maintaining an ideal weight, and engaging in regular physical activity could be encouraged at this stage as a method of primary prevention. ${ }^{24}$ In a study on the stiffness of large arterial vessels, which is attributed to aging, the only studied factor that could explain the group with vessels that did not show signs of age was the lowest BP level presented. ${ }^{95}$

\section{Sedentary behavior}

The death rate from cardiovascular disease is lower in individuals who exercise regularly, and there are no doubts about the improvement in quality of life that is achieved through a physical conditioning program. However, this improvement depends on a proper prescription, and intensity, duration, and modality have an important role for a satisfactory result. In adults, the recommended physical conditioning activities lie between the ventilatory threshold and the respiratory compensation point; that range is most recommended for its beneficial effects on cardiopulmonary capacity. ${ }^{96} \mathrm{In}$ children, the beneficial effects associated with physical activity include weight control, effects on cholesterol levels and insulin resistance, low BP, psychological well-being, and an increased predisposition for physical activity in young adulthood. ${ }^{797}$ Adolescents should engage in physical activities of moderate to vigorous intensity for at least 60 minutes a day, 5 days a week; this activity can be in or outside school and can be structured. ${ }^{97}$

A major challenge for public health authorities has been to increase the cardiorespiratory fitness of the population. Childhood and adolescence appear to be periods for promoting good physical activity habits and preventing sedentary 
behavior in adulthood. Therefore, the prevention of cardiovascular disease is also a pediatric problem. ${ }^{5}$ In recent decades, children have become less physically active, with energy expenditure approximately $600 \mathrm{kcal} /$ day lower than their contemporaries 50 years ago. ${ }^{98}$ Physical inactivity is recognized as an important determinant of chronic diseases, and an increase in the prevalence of these diseases during childhood has been documented..$^{9}$

Attention has been drawn to the need for physical education programs in schools and for community recreation facilities. However, few empirical studies have been conducted to determine the impact of such facilities and programs on physical activity and the level of inactivity in adolescents. ${ }^{100}$ Among adolescents, there is a trend to engage less in school physical education activities and vigorous activities and to spend more time watching television. ${ }^{101,102}$ These behaviors can affect future health problems, whereas greater physical fitness has been linked to a lower cardiovascular risk profile in children and adolescents. ${ }^{103}$

Identifying population values of maximal oxygen consumption $\left(\mathrm{VO}_{2 \max }\right)$ is important in studies that attempt to relate physical fitness to cardiovascular risk. $\mathrm{VO}_{2 \max }$ is a measurement that is used to guide the prescription of exercise and analyze the effect of training programs. ${ }^{104,105}$ Aerobic capacity measured through $\mathrm{VO}_{2 \max }$ depends on cardiovascular, respiratory, and hematological components, and the oxidative mechanisms of muscle in exercise. This value is determined by means of cardiopulmonary exercise testing, which allows the simultaneous assessment of the cardiovascular and respiratory systems' ability to perform their main functions, such as gas exchange. ${ }^{104}$ Measurements of gas exchange are fundamental to understand the limitations of exercise. However, multiple paths (direct or indirect) have been used to determine cardiorespiratory fitness. The differences in the methods used may be responsible for the differences found in the predictive power of this important physiological variable and whether cardiorespiratory fitness can serve as a predictor of blood lipids in children. ${ }^{106}$ However, the expected increase in BP with age is lower in children with better physical fitness. ${ }^{107}$

Adolescence is the period of transition to adulthood, during which many structural, hormonal, and biochemical changes occur in physiological systems that affect $\mathrm{VO}_{2 \max }{ }^{108}$ Thus, it is necessary to establish specific $\mathrm{VO}_{2 \max }$ values for this population. The international literature offers benchmarks for healthy children and adolescents..$^{15,104,109}$

Described as a behavior, physical activity includes many types of muscular activity that significantly increase energy expenditure. Physical fitness is described as an attribute, and generally refers to the ability to perform physical work; in addition, physical fitness is considered an adaptive state and is partly genetically determined. ${ }^{110}$ Physical fitness measurements are preferred over physical activity measurements because they are more objective and less error-prone. In addition, aerobic fitness and physical activity correlate better with cardiovascular diseases. Thus, efforts should be intensified to identify the starting point for daily physical activity to increase physical fitness in youth. ${ }^{110-112}$ However, determining this variable is not yet a global reality, and empirical evaluations have been performed. The use of cardiopulmonary exercise testing makes it possible to assess metabolic and cardiopulmonary capacity accurately through direct measurements of $\mathrm{VO}_{2 \text { max }}$. This value is the most important physiological measurement for determining aerobic capacity, the accurate level of physical fitness, and therefore the correct intensity of exercise to obtain the health benefits of a fitness program. ${ }^{96}$

\section{Conclusion}

Although the manifestation of coronary heart disease occurs in adulthood, detecting risk factors during childhood is crucial for establishing a prognosis and preventing damage to target organs in adults. Thus, detection and prevention should begin during childhood, when changes in lifestyle can reduce the incidence and severity of heart disease. School seems to be the key to achieving this goal.

Studies of cardiovascular risk factors in a region, city, or country should always report the prevalence and its correlations in childhood as a fundamental step in identifying a population at risk.

The studies reviewed here note the gravity of the public health problem represented by coronary heart disease. It is imperative to discuss the issues of health promotion and the prevention of future diseases that arise from the risk factors mentioned in this review.

Autopsy studies clearly indicate that atherosclerotic lesions appear during childhood. Therefore, if the risk factors for cardiovascular diseases begin in childhood, they should be addressed at this stage. This timing reinforces the need for rigorous pediatric care in this age-group for an early diagnosis, particularly counseling regarding preventive measures. For example, dyslipidemia, which is the major known risk factor, can be modified by a moderate fat restriction without impairing the growth and development of children older than 2 years of age. Thus, it is possible to achieve a great impact on cardiovascular disease through research on evaluation of risk factors in asymptomatic children. 
Therefore, it would be beneficial to identify those children and adolescents with the highest risk as early in life as possible, so that interventions to reduce cardiovascular risk could be targeted. Indeed, there are existing guidelines on screening of dyslipidemia, elevated BP, and obesity in childhood; however, there is a shortage of data on the optimal age for screening of cardiovascular disease risk factors in childhood.

It is necessary to raise social awareness at all levels and develop studies to plan programs and actions to control dyslipidemia, obesity, high BP, and a sedentary lifestyle at an early age so that they do not become the epidemics of this new century.

\section{Acknowledgment}

The authors thank Geraldo Magela Freitas dos Santos for editing, formatting, and proofreading this study.

\section{Disclosure}

The authors have nothing to declare.

\section{References}

1. Kelishadi R, Zadegan NS, Naderi GA, Asgary S, Bashardoust N. Atherosclerosis risk factors in children and adolescents with or without family history of premature coronary artery disease. Med Sci Monit. 2002;8:425-429.

2. Strong WB, Kelder SH. Pediatric preventive cardiology. In: Manson JE, Ridker PM, Gaziano DM, Hennekens CH, editors. Prevention of Myocardial Infarction. Oxford: Oxford University Press; 1996:433-459.

3. Lotufo PA. Novos conceitos sobre uma Velha Realidade. In: Mion D Jr, Nobre F, editors. Risco Cardiovascular Global. São Paulo: Lemos Editoria; 1999:31-43.

4. Pellanda LC, Echenique L, Barcellos LMA, MaccarI J, Borges FK, Zen BL. Doença cardíaca isquêmica: a prevenção inicia durante a infância. J Pediatr. 2002;78:91-96.

5. Massin M, Vandoorne C, Coremans C, Lepage P, Scheen A. Preventive cardiology: strategies in children. Rev Med Liege. 2002;57:207-212.

6. Michaelsen KF, Dyerberg J, Falk E, et al. Children, fat and cardiovascular diseases. Ugeskr Laeger. 2002;164:1334-1338. Danish.

7. Williams CL, Hayman LL, Daniels SR, et al. Cardiovascular health in childhood: a statement for health professionals from the Committee on Atherosclerosis, Hypertension, and Obesity in the Young (AHOY) of the Council on Cardiovascular Disease in the Young, American Heart Association. Circulation. 2002;106:143-160.

8. Srinivasan SR, Myers L, Berenson GS. Distribution and correlates of non-high-density lipoprotein cholesterol in children: the Bogalusa Heart Study. Pediatrics. 2002;110:29-32.

9. Lenfant C, Savage PJ. The early natural history of atherosclerosis and hypertension in the young: National Institutes of Health perspectives. Am J Med Sci. 1995;310 Suppl 1:S3-S7.

10. Purath J, Lansinger T, Ragheb C. Cardiac risk evaluation for elementary school children. Public Health Nurs. 1995;12:189-195.

11. Gerber ZRS, Zielinsky P. Fatores de Risco de Aterosclerose na infância. Um Estudo Epidemiológico. Arq Bras Cardiol. 1997;69:231-236.

12. Akerblom HK, Viikari J, Raitakari OT, Uhari M. Cardiovascular risk in Young Finns Study: general outline and recent developments. Ann Med. 1999;31:45-54.

13. Hedley AA, Ogden CL, Johnson CL, Carroll MD, Curtin LR, Flegal KM. Prevalence of overweight and obesity among US children, adolescents, and adults, 1999-2002. JAMA. 2004;291:2847-2850.
14. Eckel RH, York DA, Rössner S, et al. Prevention Conference VII: Obesity, a worldwide epidemic related to heart disease and stroke: executive summary. Circulation. 2004;110:2968-2975.

15. Rodrigues AN, Moyses MR, Bissoli NS, Pires JGP, Abreu GR. Cardiovascular risk factor in a population of Brazilian schoolchildren. Braz J Med Biol Res. 2006;39:1637-1642.

16. Rodrigues AN, Perez AJ, Pires JG, et al. Cardiovascular risk factors, their associations and presence of metabolic syndrome in adolescents. J Pediatr (Rio J). 2009;85:55-60.

17. Santos MG, Pegoraro M, Sandrini F, Macuco EC. Fatores de risco no desenvolvimento da aterosclerose na infância e adolescência. Arq Brás Cardiol. 2008;90:301-308.

18. Berlin JA, Colditz GA. A meta-analysis of physical activity in the prevention of coronary heart disease. Am J Epidemiol. 1996;132:612-628.

19. Esrey KL, Joseph L, Grover SA. Relationship between dietary intake and coronary heart disease mortality: lipid research clinics prevalence follow-up study. J Clin Epidemiol. 1996;49:211-216.

20. Guedes DP, Guedes JERP. Atividade física, aptidão cardiorrespiratória, composição da dieta e fatores de risco predisponentes às doenças cardiovasculares. Arq Bras Cardiol. 2001;77:243-250.

21. Austin MA. Epidemiology of hypertriglyceridemia and cardiovascular disease. Am J Cardiol. 1999;83:13F-16F.

22. Coelho OR, Ueti OM, Almeida A. Lípides como fator de risco. In: Mion D Jr, Nobre F, editors. Risco Cardiovascular Global. São Paulo: Lemos Editorial; 1999:45-64.

23. Françoso LA, Coates V. Evidências anatomopatológicas do início da aterosclerose na infância e adolescência. Arq Bras Cardiol. 2002;78: 131-136.

24. Massin M, Coremans C, Palumbo L, Lepage P. Preventive cardiology: the role of the pediatrician. Ital J Pediatr. 2002;28:98-104.

25. Brotons C, Ribera A, Perich RM, et al. Worldwide distribution of blood lipids and lipoproteins in childhood and adolescence: a review study. Atherosclerosis. 1998;139:1-9.

26. Halpern A, Mancini MC, Magalhães MEC, et al. Metabolic syndrome, dyslipidemia, hypertension and type 2 diabetes in youth: from diagnosis to treatment. Diabetol Metab Syndr. 2010;2:55.

27. Giuliano ICB, Caramelli B. Dislipidemias em crianças e adolescentes. Rev Soc Cardiol Estado São Paulo. 2005;6:535-543.

28. Guimarães AC, Lima A, Mota E, et al. The cholesterol level of a selected Brazilian salaried population: biological and socioeconomic influences. CVD Prev. 1998;1:306-317.

29. Guimarães ICB, Guimarães AC. Prevalence of cardiovascular risk factors in selected samples of schoolchildren - socioeconomic influence. Prev Cardiol. 2005;8:23-28.

30. Hokanson JE, Austin MA. Plasma triglyceride level is a risk factor for cardiovascular disease independent of high-density lipoprotein cholesterol level: a meta-analysis of population-based prospective studies. J Cardiovasc Risk. 1996;3:213-219.

31. Gaziano DM, Hennekens CH, editors. Prevention of Myocardial Infarction. Oxford: Oxford University Press; 1996:433-459.

32. Golding J, Emmet PM, Rogers IS. Does breast feeding have any impact on non-infectious, non-allergic disorders? Early Hum Dev. 1997; 49 Suppl:S131-S142.

33. Forti N, Giannini SD, Diament J, et al. Fatores de risco para aterosclerose em filhos de pacientes com doença coronariana precoce. Arq Bras Cardiol. 1996;66:119-123.

34. Rodrigues AN, Abreu GR, Gouvêa SA. Cardiovascular risk investigation: when should it start? In: Gasparyan AY, editor. Cardiovascular Risk Factors. Rijeka, Croatia: InTech; 2012.

35. Alonso-Martinez JL, Llorente-Diez B, Echegaray-Agara M, Olaz-Preciado F, Urbieta-Echezarreta M, González-Arencibia C. C-reactive protein as a predictor of improvement and readmission in heart failure. Eur J Heart Fail. 2002;4:331-336.

36. Maeda K, Tsutamoto T, Wada A, et al. High levels of plasma brain natriuretic peptide and interleukin- 6 after optimized treatment for heart failure are independent risk factors for morbidity and mortality in patients with congestive heart failure. J Am Coll Cardiol. 2000;36:1587-1593. 
37. Vasan RS, Sullivan LM, Roubenoff R, et al. Inflammatory markers and risk of heart failure in elderly subjects without prior myocardial infarction: the Framingham Heart Study. Circulation. 2003; 107(11):1486-1491.

38. Toprak A, Kandavar R, Toprak D, et al. C-reactive protein is an independent predictor for carotid artery intima-media thickness progression in asymptomatic younger adults (from the Bogalusa Heart Study). BMC Cardiovasc Disord. 2011;11:78.

39. Kelishadi R. Inflammation-induced atherosclerosis as a target 1 for prevention of cardiovascular diseases from early life. Open Cardiovasc Med J. 2010;4:24-29.

40. Sorensen TIA. The genetics of obesity. Metabolism. 1995;44 Suppl 3: 4-6.

41. Troiano RP, Flegal KM. Overweight children and adolescents: description, epidemiology and demographics. Pediatrics. 1998;101 Suppl 3: 497-504.

42. Gunnell DJ, Frankel SJ, Nanchahal K, Peters TJ, Smith GD. Childhood obesity and adult cardiovascular mortality: a 57-y follow-up study based on the Boyd Orr cohort. Am J Clin Nutr. 1998;67:1111-1118.

43. VanHorn L, Greenland P. Prevention of coronary artery disease is a pediatric problem. JAMA. 1997;278:1779-1780.

44. Kikuchi DA, Srinivasan SR, Harsha DW, Webber LS, Sellers TA, Berenson GS. Relation of serum lipoprotein lipids and apolipoproteins to obesity in children: the Bogalusa Heart Study. Prev Med. 1992;21:177-190.

45. Zanella MT. Obesidade. In: Mion D Jr, Nobre F, editors. Risco Cardiovascular Global. São Paulo: Lemos Editorial; 1999: 103-114.

46. Cali AM, Caprio S. Obesity in children and adolescents. Clin Endocrinol Metab. 2008;93:S31-S36.

47. Lloyd LJ, Langley-Evans SC, McMullen S. Childhood obesity and adult cardiovascular disease: a systematic review. Int J Obes (Lond). 2010;34:18-28.

48. Coronelli CLS, Moura EC. Hipercolesterolemia em escolares e seus fatores de risco. Rev Saude Publica. 2003;37:24-31.

49. Alves JGB, Siqueira PP, Figueiroa JN. Overweight and physical inactivity in children living in favelas in the metropolitan region of Recife, Brazil. J Pediatr (Rio J). 2009;85:67-71.

50. Daniels SR, Arnett DK, Eckel RH, et al. Overweight in children and adolescents: pathophysiology, consequences, prevention, and treatment. Circulation. 2005;111:1999-2012.

51. Buiten C, Metzger B. Childhood obesity and risk of cardiovascular disease: a review of the science. Pediatr Nurs. 2000;26:13-18.

52. Waters E, de Silva-Sanigorski A, Hall BJ, et al. Interventions for preventing obesity in children. Cochrane Database Syst Rev. 2011;12:CD001871.

53. Summerball CD, Moore HJ, Vogele C, et al. Evidence-based recommendations for the development of obesity prevention programs targeted at preschool children. Obes Rev. 2012;13 Suppl 1:129-132.

54. Giugliano R, Melo ALP. Diagnóstico de sobrepeso e obesidade em escolares: utilização do índice de massa corporal segundo padrão internacional. J Pediatr. 2004;80:129-134.

55. Mello ED, Luft VC, Meyer F. Obesidade infantil: como podemos ser eficazes? J Pediatr. 2004;80:173-182.

56. Bueno MB, Marchioni DM, Fisberg RM. Changes in the nutritional status of children in public day care facilities in the municipality of São Paulo, Brazil. Rev Panam Salud Publica. 2003;14:165-170.

57. Silva DAS, Pelegrini A, Petroski EL, Gaya ACA. Comparison between the growth of Brazilian children and adolescents and the reference growth charts: data from a Brazilian project. J Pediatr (Rio J). 2010;86:115-120.

58. Abrantes MM, Lamounier JA, Colosimo EA. Prevalência de sobrepeso e obesidade em crianças e adolescentes das regiões Sudeste e Nordeste. J Pediatr. 2002;78:335-340.

59. Moura AA, Silva MAM, Ferraz MRMT, Rivera IR. Prevalência de pressão arterial elevada em escolares e adolescentes de Maceió. J Pediatr. 2004;80:35-40.
60. O’Brien SH, Holubkoy R, Reis EC. Identification, evaluation, and management of obesity in an academic primary care center. Pediatrics. 2004;114:154-159.

61. Reavens GM, Lithell H, Landsberg L. Hypertension and associated abnormalities - the role of insulin resistance and the sympathoadrenal system. N Engl J Med. 1996;334:74-81.

62. Brandão AP, Brandão AA, Berenson GS, Fuster V. Metabolic syndrome in children and adolescents. Arq Bras Cardiol. 2005;85:79-81.

63. Lakka HM, Laaksonen DE, Lakka TA, et al. The metabolic syndrome and total cardiovascular disease mortality in middle-aged men. JAMA. 2002;288:2709-2716.

64. Alberti KG, Zimmet PZ. Definition, diagnosis and classification of diabetes mellitus and its complications. Part 1: diagnosis and classification of diabetes mellitus provisional report of a WHO consultation. Diabet Med. 1998;15:539-553.

65. National Cholesterol Education Program. Detection, Evaluation, and Treatment of High Blood Cholesterol in Adults (Adult Treatment Panel III). Bethesda (MD): National Institutes of Health; 2002.

66. Balkau B, Charles MA. Comment on the provisional report from the WHO consultation. European Group for the Study of Insulin Resistence (EGIR). Diabet Med. 1999;16:442-443.

67. Cook S, Weitzman M, Auinger P, Nguyen M, Dietz WH. Prevalence of a metabolic syndrome phenotype in adolescents: findings from the third National Health and Nutrition Examination Survey, 1988-1994. Arch Pediatr Adolesc Med. 2003;157:821-827.

68. Csábi G, Török K, Jeges S, Molnár D. Presence of metabolic cardiovascular syndrome in obese children. Eur J Pediatr. 2000;159: 91-94.

69. Srinivasan SR, Myers L, Berenson GS. Predictability of childhood adiposity and insulin for developing insulin resistance syndrome (syndrome X) in young adulthood: the Bogalusa Heart Study. Diabetes. 2002;51:204-209.

70. National High Blood Pressure Education Program Working Group on High Blood Pressure in Children and Adolescents. The fourth report on the diagnosis, evaluation, and treatment of high blood pressure in children and adolescents. Pediatrics. 2004;114:555-576.

71. The Expert Committee on the Diagnosis and Classification of Diabetes Mellitus. Report of the expert committee on the diagnosis and classification of diabetes mellitus. Diabetes Care. 1999;22 Suppl 1: S5-S19.

72. Isomaa B, Almgren P, Tuomi T, et al. Cardiovascular morbidity and mortality associated with the metabolic syndrome. Diabetes Care. 2001;24:683-689.

73. Taskinen MR. Diabetic dyslipidemia: from basic research to clinical practice. Diabetologia. 2003;46:733-749.

74. Morton NM, Holmes MC, Fievet C, et al. Improved lipid and lipoprotein profile, hepatic insulin sensitivity and glucose tolerance in 11 beta hydroxyesteroid dehydrogenase type 1 null mice. J Biol Chem. 2001;276:41293-41300.

75. Weiss R, Dziura J, Burgert TS, et al. Obesity and the metabolic syndrome in children and adolescents. N Engl J Med. 2004;350:2362-2374.

76. Cadernos de Atenção Básica. Hipertensão Arterial Sistêmica. Brasilia: Ministério da Saúde; 2006.

77. Falkner B, Gidding SS, Portman R, Rosner B. Blood pressure variability and classification of prehypertension and hypertension in adolescence. Pediatrics. 2008;122:238-242.

78. Raj M. Essential hypertension in adolescents and children: recent advances in causative mechanisms. Indian $J$ Endocrinol Metab. 2011;15 Suppl 4: S367-S373.

79. Oliveira RG, Lamounier JA, Oliveira ADB, Castro MDR, Oliveira JS. Blood pressure in school children and adolescents - the Belo Horizonte study. J Pediatr (Rio J). 1999;75:256-266. Portuguese.

80. Salgado CM, Carvalhaes JTA. Arterial hypertension in childhood J Pediatr (Rio J). 2003;79 Suppl 1:S115-S124.

81. Mcmillen C, Robinson JS. Developmental origins of the metabolic syndrome: prediction, plasticity, and programming. Physiol Rev. 2005;85:571-633. 
82. Carlson SH, Oparil S, Chen YF, Wyss JM. Blood pressure and NaClsensitive hypertension are influenced by angiotensin-converting enzyme gene expression in transgenic mice. Hypertension. 2002;39: 214-218.

83. Rosa AA, Ribeiro JP. High blood pressure in children and adolescents: determinant factors. J Pediatr (Rio J). 1999;75:75-82.

84. Kavey REW, Daniels SR, Lauer RM, Atkins DL, Hayman LL, Taubert K. American Heart Association guidelines for primary prevention of atherosclerotic cardiovascular disease beginning in childhood. Circulation. 2003;107:1562-1566.

85. Chobanian AV, Bakris GL, Black HR, et al. The Seventh Report of the Joint National Committee on Prevention, Detection, Evaluation, and Treatment of High Blood Pressure: the JNC 7 report. JAMA. 2003;289:2560-2572.

86. Lieberman E. Hypertension in childhood and adolescence. In: Kaplan NM, editor. Clinical Hypertension, 8th ed. Baltimore: Williams \& Wilkins; 2002:512-526.

87. Sociedade Brasileira de Cardiologia/Sociedade Brasileira de Hipertensão/Sociedade Brasileira de Nefrologia. VI Diretrizes Brasileiras de Hipertensão. Arq Bras Cardiol. 2010;95:1-51.

88. Sorof J, Daniels S. Obesity hypertension in children: a problem of epidemic proportions. Hypertension. 2002;40:441-447.

89. Campana ANNB, Tavares MCGCF. Avaliação da Imagem Corporal: Instrumentos e Diretrizes para a Pesquisa. São Paulo: Phorte; 2009.

90. European Society of Hypertension. Guidelines for the management of arterial hypertension. J Hypertens. 2003;21:1011-1053.

91. [No authors listed]. The effects of nonpharmacologic interventions on blood pressure of persons with high normal levels. Results of the Trials of Hypertension Prevention, phase I. JAMA. 1992;267:1213-1220.

92. Monteiro CA, Conde WL, Castro IR. The changing relationship between education and risk of obesity in Brazil (1975-1997). Cad Saude Publica. 2003;19 Suppl 1:S67-S75. Portuguese.

93. Rosa ML, Fonseca VM, Oigman G, Mesquita ET. Arterial prehypertension and elevated pulse pressure in adolescents: prevalence and associated factors. Arq Bras Cardiol. 2006;87:46-53. Portuguese.

94. Srinivasan SR, Myers L, Berenson GS. Changes in metabolic syndrome variables since childhood in prehypertensive and hypertensive subjects: the Bogalusa Heart Study. Hypertension. 2006;48:33-39.

95. Rodrigues AN, Coelho LC, Goncalves WL, et al. Stiffness of the large arteries in individuals with and without Down syndrome. Vasc Health Risk Manag. 2011;7:375-381.

96. Rondon MUPB, Forjaz CLM, Nunes N, Amaral SL, Barretto ACPB, Negrão CE. Comparação entre a prescrição de intensidade de treinamento físico baseada na avaliação ergométrica convencional e na ergoespirometria. Arq Bras Cardiol. 1998;70:159-166.
97. Strong WB, Malina RM, Blimkie CJ, et al. Evidence based physical activity for school-age youth. J Pediatr. 2005;146:732-737.

98. Boreham C, Riddoch C. The physical activity, fitness and health of children. J Sports Sci. 2001;19:915-929.

99. Twisk JW. Physical activity guidelines for children and adolescents: a critical review. Sports Med. 2001;31:617-627.

100. Gordon-Larsen P, McMurray RG, Popkin BM. Determinants of adolescent physical activity and inactivity patterns. Pediatrics. 2000; 105:E83

101. Freedman DS, Srinivasan SR, Valdez RA, Williamson DF, Berenson GS. Secular increases in relative weight and adiposity among children over two decades: the Bogalusa Heart Study. Pediatrics. 1997;99:420-426.

102. Lippo BRS, Silva IM, Aca CRP, Lira PIC, Silva GAP, Motta MEFA. Determinants of physical inactivity among urban adolescents. J Pediatr (Rio J). 2010;86:520-524

103. Al-Hazaa HM. Physical activity, fitness and fatness among Saudi children and adolescents: implications for cardiovascular health. Saudi Med J. 2002;23:144-150.

104. Armstrong N, Welsman JR. Assessment and interpretation of aerobic fitness in children and adolescents. Exerc Sport Sci Rev. 1994;22:435-476.

105. Obert P, Mandigout S, Nottin S, Vinet A, N'Guyen D, Lecoq A. Cardiovascular responses to endurance training in children: effect of gender. Eur J Clin Invest. 2003;33:199-208.

106. Tolfrey K, Campbell IG, Jone AM. Selected predictor variables and the lipid-lipoprotein profile of prepubertal girls and boys. Med Sci Sports Exerc. 1999;31:1550-1557.

107. Shea S, Basch CE, Gutin B, et al. The rate of increase in blood pressure in children 5 years of age is related to changes in aerobic fitness and body mass index. Pediatrics. 1994;94:465-470.

108. Tourinho Filho H, Tourinho LSPR. Crianças, adolescentes e atividade física: aspectos maturacionais e funcionais. Rev Paul Educ Fis. 1998;12:71-84.

109. Turley KR, Wilmore JH. Cardiovascular responses to treadmill and cycle ergometer exercise in children and adults. J Appl Physiol. 1997;83:948-957.

110. Thomas NE, Baker JS, Davies B. Established and recently identified coronary heart disease risk factors in young people: the influence of physical activity and physical fitness. Sports Med. 2003;33:633-650.

111. Bouchard C, Dionne FT, Simoneau JA, Boulay MR. Genetics of aerobic and anaerobic performances. Exerc Sport Sci Rev. 1992;20:27-58.

112. McMurray RG, Ainsworth BE, Harrell JS, Griggs TR, Williams OD. Is physical activity or aerobic power more influential at reducing cardiovascular disease risk factors? Med Sci Sports Exerc. 1998;30:1521-1529.
International Journal of General Medicine

\section{Publish your work in this journal}

The International Journal of General Medicine is an international, peer-reviewed open-access journal that focuses on general and internal medicine, pathogenesis, epidemiology, diagnosis, monitoring and treatment protocols. The journal is characterized by the rapid reporting of reviews, original research and clinical studies across all disease areas.

\section{Dovepress}

A key focus is the elucidation of disease processes and management protocols resulting in improved outcomes for the patient.The manuscript management system is completely online and includes a very quick and fair peer-review system. Visit http://www.dovepress.com/ testimonials.php to read real quotes from published authors. 